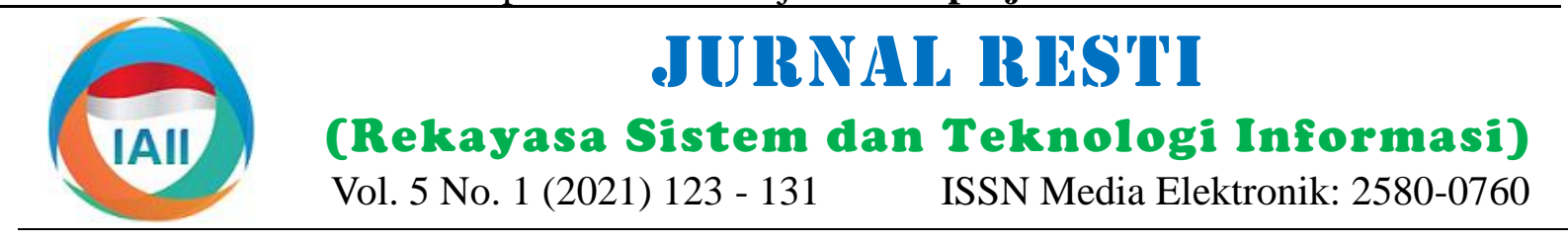

\title{
Analisis Sentimen dan Pemodelan Topik Pariwisata Lombok Menggunakan Algoritma Naive Bayes dan Latent Dirichlet Allocation
}

\author{
Ni Luh Putu Merawati ${ }^{1}$, Ahmad Zuli Amrullah ${ }^{2}$, Ismarmiaty ${ }^{3}$ \\ ${ }^{1,2}$ Teknologi Informasi, Teknik dan Desain, Universitas Bumigora \\ ${ }^{3}$ Sistem Informasi, Teknik dan Desain, Universitas Bumigora \\ 1'putu.mera@universitasbumigora.ac.id, ${ }^{2}$ zuli@universitasbumigora.ac.id, ${ }^{3}$ ismarmiaty@ universitasbumigora.ac.id
}

\begin{abstract}
Lombok Island is one of the favorite tourist destinations. Various topics and comments about Lombok tourism experience through social media accounts are difficult to manually identify public sentiments and topics. The opinion expressed by tourists through social media is interesting for further research. This study aims to classify tourists' opinions into two classes, positive and negative, and topics modelling by using the Naive Bayes method and modeling the topic by using Latent Dirichlet Allocation (LDA). The stages of this research include data collection, data cleaning, data transformation, data classification. The results performance testing of the classification model using Naive Bayes method is shown with an accuracy value of $92 \%$, precision of $100 \%$, recall of $84 \%$ and specificity of $100 \%$. The results of modeling topics using LDA in each positive and negative class from the coherence value shows the highest value for the positive class was obtained on the 8th topic with a value of 0.613 and for the negative class on the 12th topic with a value of 0.528. The use of the Naive Bayes and LDA algorithms is considered effective for analyzing the sentiment and topic modelling for Lombok tourism.
\end{abstract}

Keywords: sentiment analysis, probabilistic computing, machine learning, tourism

\begin{abstract}
Abstrak
Pulau Lombok menjadi salah satu tujuan wisata favorit di Indonesia. Beragam topik maupun komentar tentang Lombok disampaikan wisatawan melalui akun pribadi media sosialnya sehingga sangat sulit untuk melakukan identifikasi sentimen publik maupun topik pembicaraan secara manual. Opini yang disampaikan wisatawan melalui media sosial khususnya twitter tentang pariwisata Lombok, menarik untuk diteliti lebih lanjut. Penelitian ini bertujuan untuk melakukan klasifikasi opini-opini wisatawan menjadi dua kelas yaitu positif dan negatif serta melakukan pemodelan topik pada kedua kelas tersebut. Pemodelan topik bertujuan untuk mengetahui topik yang sering dibicarakan pada masing-masing kelas. Tahapan dari penelitian ini meliputi pengumpulan data, pembersihan data, transformasi data, klasifikasi data dengan metode Naive Bayes dan penggunaan metode Latent Dirichlet Allocation (LDA) untuk pemodelan topik. Hasil pengujian kinerja model menggunakan algoritma Naive Bayes ditunjukkan dengan nilai akurasi, presisi, recall dan spesifisitas masing-masing sebesar $92 \%, 100 \%, 83,84 \%$ dan $100 \%$. Hasil pemodelan topik dengan metode LDA pada masing-masing kelas positif dan negatif dapat dilihat dari nilai koherensi yaitu semakin tinggi nilai koherensi suatu topik maka semakin mudah topik tersebut diinterpretasikan oleh manusia. Nilai koherensi tertinggi untuk kelas positif diperoleh pada topik ke 8 dengan nilai sebesar 0,613 dan untuk kelas negatif pada topik ke 12 dengan nilai sebesar 0,528. Penggunaan algoritma Naive Bayes dan LDA dinilai efektif untuk analisis sentimen serta pemodelan topik untuk pariwisata Lombok.
\end{abstract}

Kata kunci: analisis sentimen, komputasi probabilistik, pembelajaran mesin, pariwisata

\section{Pendahuluan}

Pulau Lombok merupakan salah satu bagian wilayah administratif daerah tingkat 1 Provinsi Nusa Tenggara Barat (NTB) sehingga pulau Lombok menjadi pilihan utama untuk pengembangan pariwisata NTB dibandingkan dengan pulau lainnya yang masuk wilayah NTB. Dinamika ini sejalan dengan upaya pemerintah daerah untuk menjadikan sektor pariwisata sebagai salah satu program unggulan provinsi Nusa Tenggara Barat (NTB). Sektor pariwisata diyakini mampu menjadi sumber pertumbuhan ekonomi baru di Lombok. Selain itu Lombok ditargetkan menjadi salah satu pintu gerbang pariwisata nasional untuk wilayah Nusa Tenggara [1] . Para wisatawan yang datang berkunjung ke suatu daerah

Diterima Redaksi: 24-10-2020 | Selesai Revisi: 18-02-2021 | Diterbitkan Online: 20-02-2021 
wisata mampu memberikan andil yang besar dalam Berdasarkan penelitian yang telah dilakukan, banyak pertumbuhan ekonomi daerah sehingga pengembangan peneliti melakukan eksplorasi data teks melalui kepariwisataan Lombok sangat perlu dilakukan sebagai klasifikasi untuk menghasilkan informasi yang penting salah satu upaya untuk mendukung perkembangan seperti penelitian yang dilakukan [9] tentang analisis kepariwisataan nasional [2].

Secara umum perkembangan pariwisata Lombok masih cukup lambat jika dibandingkan dengan daerah lain di Indonesia seperti Bali, Yogyakarta, Bandung, Malang, dan lain-lain. Faktor-faktor yang mempengaruhi lambatnya perkembangan wisata Lombok antara lain ketersediaan fasilitas pendukung kepariwisataan masih sangat terbatas mulai dari akses hingga infrastruktur [2] serta masih minimnya pemanfaatan teknologi informasi dalam pengelolaan kepariwisataan daerah.

Pertumbuhan media sosial yang cukup pesat saat ini dan metode query expansion ranking untuk mengurangi tidak lepas dari pengaruh perkembangan teknologi jumlah fitur pada proses klasifikasi. Hasil penelitian informasi. Media sosial adalah media informasi paling menghasilkan akurasi sebesar 86,6\%. Kemudian [11] diminati masyarakat saat ini serta merupakan media melakukan analisis sentimen pemeringkatan popularitas untuk bersosialisasi satu sama lain secara online. tujuan wisata menggunakan algoritma naive bayes Keberadaan media sosial memberikan banyak manfaat, dengan nilai akurasi sebesar 82,67\%. Selanjutnya [12] salah satunya adalah masyarakat menggunakan media melakukan analisis sentimen twitter tentang pariwisata sosial sebagai tempat untuk menyampaikan opini atau Lombok. Penelitian ini menggunakan metode naive pendapat, kritik, saran secara bebas [3]. Twitter bayes serta mutual information untuk seleksi fitur merupakan salah satu media sosial yang populer dengan nilai akurasi sebesar 97,9\%.

dikalangan masyarakat Indonesia karena mampu memberikan informasi secara cepat dan real time. Twitter menjadi wadah penyampaian opini masyarakat dalam bentuk saran, kritikan, maupun pendapat. Twitter dapat menjadi sumber informasi yang tepat untuk menggali opini masyarakat melalui cuitan-cuitan yang dilontarkan terhadap suatu berita atau kejadian dengan topik tertentu. Twitter dapat digunakan untuk mengetahui isi pikiran atau sentimen pemilik akun [4].

Sentimen yang disampaikan masyarakat melalui twitter yang jumlah danya banyak, besar dan beragam serta mengandung informasi yang sangat berharga untuk dalam [13] mengemukakan bahwa naive bayes adalah dianalisis [5]. Penggalian informasi dari sekumpulan algoritma yang sederhana dan bagus untuk klasifikasi tweet sulit dilakukan secara manual karena jumlah tweet teks. Selain itu penelitian ini juga berfokus untuk yang di post perhari sangat banyak dengan topik ulasan mengidentifikasi topik yang paling banyak dibicarakan beragam sehingga membutuhkan model analisis data pada masing-masing kelas yaitu positif dan negatif yang cepat dan tepat. Model analisis data seperti analisis menggunakan metode Latent Dirichlet Allocation sentimen dan pemodelan topik dapat digunakan untuk (LDA). LDA digunakan untuk menentukan beberapa membantu menemukan informasi-informasi topik yang muncul dari masing-masing opini pada setiap tersembunyi dari sekumpulan tweet [6]. Analisis kelas. Kelebihan metode LDA adalah dapat mengekstrak sentimen merupakan bagian dari text mining yang topik secara akurat pada kumpulan data yang cukup bertujuan untuk mengklasifikasi dokumen teks berupa besar [6]. Penelitian ini terbagi menjadi dua tujuan yaitu opini sehingga menghasilkan suatu informasi sentimen pertama melakukan analisis sentimen pada twitter yang dapat bermakna positif maupun negatif [7]. Metode dengan topik pariwisata Lombok menjadi dua kelas analisis sentimen dapat digunakan untuk menganalisa yaitu positif dan negatif dengan metode naive bayes pendapat maupun emosi seseorang dalam meyikapi kemudian mengukur hasil kinerja model berdasarkan sesuatu yang menyangkut topik tertentu[8] misalnya empat kriteria yaitu akurasi, presisi, recall dan spesifitas. sentimen masyarakat terhadap pariwisata Lombok Kedua melakukan pemodelan topik pada masing-masing sehingga informasi mengenai kepuasan wisatawan dapat kelas positif dan negatif untuk mengidentifikasi topik diketahui. Hasil analisis sentimen tersebut dapat utama yang sering dibahas pada kedua kelas tersebut dimanfaatkan oleh pemerintah daerah, pelaku wisata menggunakan Latent Dirichlet Allocation (LDA) serta maupun stakeholder sebagai pendukung pengambilan mengukur hasil kinerja model LDA berdasarkan nilai keputusan dalam pengembangan dan pengelolaan koherensi. Hasil penelitian ini digunakan sebagai data pariwisata Lombok kedepannya. pendukung bagi para pelaku wisata di Pulau Lombok 
seperti pemerintah daerah khususnya dinas pariwisata 2.1. Pengambilan Data

maupun sektor swasta dalam pembuatan kebijakan maupun pengambilan keputusan yang berkaitan dengan pengembangan sektor pariwisata yang relevan dengan kebutuhan wisatawan seperti kebijakan untuk promosi, perbaikan fasilitas tempat wisata, penambahan fasilitas tempat wisata, penambahan fasilitas umum dan sebagainya.

\section{Metode Penelitian}

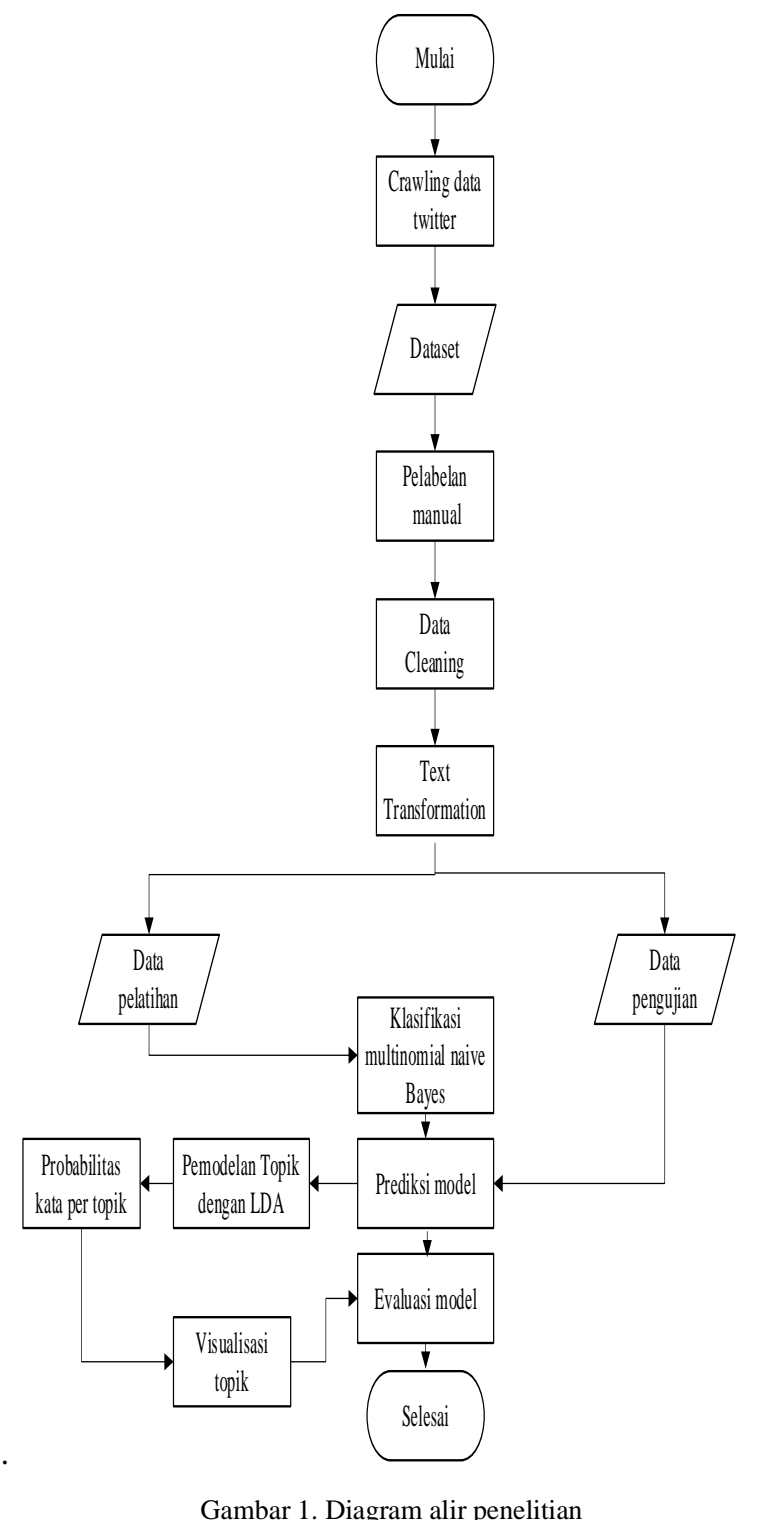

Tahapan penelitian ini secara umum ditunjukkan pada Gambar 1. Berdasarkan Gambar 1, penelitian ini mempunyai 7 tahapan penting yaitu pengumpulan data tweet, pelabelan secara manual, data cleaning, text transformation, klasifikasi tweet menggunakan multinomial naive bayes, pemodelan topik menggunakan LDA dan yang terakhir adalah tahap pengujian menggunakan metode confusion matrix
Tahap pertama pada penelitian ini adalah pengumpulan data tweet dengan topik pariwisata melalui API twitter dengan menggunakan hastag seperti \#gilitrawangan, \#wonderfulllombok, \#pantaikutamandalika, \#lombok \#beautifullombok, \#lombokindah, \#senggigibeach \#kekmandalika, \#lombokaman, dan lain-lain. Data tweet yang diambil merupakan rentang data 5 tahun terakhir yaitu dari tahun 2014 sampai 2019. Contoh data tweet yang berhasil dikumpulkan diperlihatkan pada tabel 1 . Selanjutnya seluruh data yang terkumpul akan melalui proses preprocessing bertujuan untuk pembersihan data.

\begin{tabular}{ll}
\multicolumn{2}{c}{ Tabel 1. Contoh data tweet } \\
\hline Kelas & Tweet \\
\hline Negatif & $\begin{array}{l}\text { Tak sebersih dulu lagi...\#sampah \#pantai } \\
\text { senggigi }\end{array}$ \\
Positif & Dinikmati aja,,,keindahannya... \#Lovepantai \\
\hline
\end{tabular}

\subsection{Data Cleaning}

Tahap kedua pada penelitian ini adalah proses pembersihan data bertujuan agar dataset tidak mengandung noise yang dapat mempengaruhi hasil klasifikasi. Contoh hasil data cleaning ditunjukkan tabel 2, dimana tahapan data cleaning meliputi hapus hastag pada tweet, hapus URL, hapus mention, hapus karakter tweet, hapus kata-kata yang diulang, hapus angka dan tanda baca.

Tabel 2. Hasil data cleaning

\begin{tabular}{|c|c|c|}
\hline Langkah & Sebelum & Sesudah \\
\hline $\begin{array}{l}\text { Hapus } \\
\text { hastag }\end{array}$ & $\begin{array}{l}\text { Memandang } \\
\text { keindahan laut dan } \\
\text { pantai dari atas bukit... } \\
\text { \#lombok } \\
\text { \#lombokisland } \\
\text { \#bukitmerese } \\
\text { \#meresehill } \\
\text { \#visitlombok } \\
\text { \#visitindonesia } \\
\text { \#wonderfulindonesia } \\
\text { @ Bukit Merese } \\
\text { Lombok } \\
\text { https://www.instagram } \\
\text {.com/p/BoBPFALlsm } \\
\text { G/?utm_source=ig_twi } \\
\text { tter_share\&amp }\end{array}$ & $\begin{array}{l}\text { Memandang } \\
\text { keindahan laut dan } \\
\text { pantai dari atas bukit... } \\
@ \text { Bukit Merese } \\
\text { Lombok } \\
\text { https://www.instagra } \\
\text { m.com/p/BoBPFALls } \\
\text { mG/?utm_source=ig_ } \\
\text { twitter_share\&amp }\end{array}$ \\
\hline Hapus & Memandang & Memandang \\
\hline URL & $\begin{array}{l}\text { keindahan laut dan } \\
\text { pantai dari atas bukit.... } \\
\text { @ Bukit Merese } \\
\text { Lombok } \\
\text { https://www.instagram } \\
\text {.com/p/BoBPFALlsm } \\
\text { G/?utm_source=ig_twi } \\
\text { tter_share\&amp }\end{array}$ & $\begin{array}{l}\text { keindahan laut dan } \\
\text { pantai dari atas } \\
\text { bukit.... @ Bukit } \\
\text { Merese Lombok }\end{array}$ \\
\hline $\begin{array}{l}\text { Hapus } \\
\text { mention }\end{array}$ & $\begin{array}{l}\text { Memandang } \\
\text { keindahan laut dan } \\
\text { pantai dari atas bukit.... } \\
@ \text { Bukit } \quad \text { Merese } \\
\text { Lombok }\end{array}$ & $\begin{array}{l}\text { Memandang } \\
\text { keindahan laut dan } \\
\text { pantai dari atas bukit... }\end{array}$ \\
\hline $\begin{array}{l}\text { Hapus } \\
\text { karakter }\end{array}$ & $\begin{array}{l}\text { Memandang } \\
\text { keindahan laut dan } \\
\text { pantai dari atas bukit... }\end{array}$ & $\begin{array}{l}\text { Memandang } \\
\text { keindahan laut dan } \\
\text { pantai dari atas bukit... }\end{array}$ \\
\hline
\end{tabular}




\begin{tabular}{|c|c|c|}
\hline Hapus kata & Memandang & Memandang \\
\hline yang berulan & $\begin{array}{l}\text { keindahan laut dan } \\
\text { pantai dari atas bukit... }\end{array}$ & $\begin{array}{l}\text { keindahan laut dan } \\
\text { pantai dari atas bukit... }\end{array}$ \\
\hline Hapus & Memandang & Memandang \\
\hline angka & $\begin{array}{l}\text { keindahan laut dan } \\
\text { pantai dari atas bukit... }\end{array}$ & $\begin{array}{l}\text { keindahan laut dan } \\
\text { pantai dari atas bukit... }\end{array}$ \\
\hline Hapus & Memandang & Memandang \\
\hline $\operatorname{tanda} b$ & $\begin{array}{l}\text { keindahan laut dan } \\
\text { pantai dari atas bukit }\end{array}$ & $\begin{array}{l}\text { keindahan laut dan } \\
\text { pantai dari atas bukit }\end{array}$ \\
\hline
\end{tabular}

\subsection{Text Transformation}

Tahap ketiga pada penelitian ini adalah proses text transformation. Hasil text transformation ditunjukkan pada tabel 3. Tahapan text transformation yang dilakukan pada penelitian ini terdiri dari 6 proses yaitu case folding, tokenisasi, stopword removal, lematisasi, pembobotan dan ekstraksi fitur.

a. Case folding yaitu proses mengubah semua karakter huruf menjadi huruf kecil.

b. Tokenisasi yaitu proses pemotongan dokumen $P(X \mid c)=\log \frac{N_{c}}{N}+\sum_{i=1}^{n} \log \frac{t_{i}+\alpha}{\sum_{i=1}^{n} t_{i}+\alpha}$
inputan berdasarkan tiap kata yang menyusunnya.

c. Stopword removal yaitu proses pemilihan kata-kata dengan $\mathrm{P}(\mathrm{X} \mid \mathrm{c})$ adalah probabilitas dokumen $\mathrm{X}$ pada penting yang mempunyai arti dan tidak, sehingga kelas c, Nc adalah total dokumen pada kelas c, $\mathrm{N}$ adalah kata yang tidak mempunyai arti akan dibuang, total dokumen, $\mathrm{t}_{\mathrm{i}}$ adalah bobot term $\mathrm{t}, \sum_{i=1}^{n} t$ adalah total contohnya "ini", "itu”, "yang", “di” dan lain-lain. bobot term pada kelas c, a adalah nilai parameter

d. Lematisasi adalah proses normalisasi kata untuk smoothing [16]. menemukan bentuk dasar dari kata tersebut berdasarkan bentuk lemmanya.

e. Ekstraksi fitur adalah proses mengubah kata menjadi fitur menggunakan metode Term Frequency-Inverse Document Frequency (TF-IDF). Metode ini akan menghitung kemunculan kata pada setiap dokumen kemudian memberi bobot pada kata tersebut. Proses pemberian bobot kata dipengaruhi oleh tiga faktor utama, yaitu Term Frequency (TF), Inverse Document Frequency (IDF) dan Document Length [14]. TF dihitung berdasarkan jumlah kemunculan setiap kata pada sebuah dokumen sedangkan IDF dihitung berdasarkan jumlah kemunculan kata pada seluruh dokumen. Kemudian dilakukan proses normalisasi lalu nilai TF dibandingkan terhadap nilai IDF [15]. Setelah semua kata teridentifikasi langkah selanjutnya adalah membuat tabel untuk menampung kumpulan kata tersebut dimana setiap kata akan memiliki fitur kolom yang disebut dengan text vectorization. Hasil vektor ini digunakan sebagai fitur untuk pelatihan dan pengujian klasifikasi.

Tabel 3. Hasil text transformation

\begin{tabular}{|c|c|c|}
\hline Langkah & Sebelum & Sesudah \\
\hline Case folding & Memandang & memandang \\
\hline Tokenisasi & $\begin{array}{l}\text { keindahan laut dan } \\
\text { pantai dari atas bukit } \\
\text { memandang }\end{array}$ & $\begin{array}{l}\text { keindahan laut dan } \\
\text { pantai dari atas bukit } \\
\text { 'memandang', }\end{array}$ \\
\hline & $\begin{array}{l}\text { keindahan laut dan } \\
\text { pantai dari atas bukit }\end{array}$ & $\begin{array}{l}\text { 'keindahan', 'laut', } \\
\text { 'dan', 'pantai', 'dari', } \\
\text { 'atas', 'bukit' }\end{array}$ \\
\hline $\begin{array}{l}\text { Stopword } \\
\text { removal }\end{array}$ & $\begin{array}{l}\text { memandang } \\
\text { keindahan laut dan } \\
\text { pantai dari atas bukit }\end{array}$ & $\begin{array}{l}\text { 'memandang', } \\
\text { 'keindahan', 'pantai', } \\
\text { 'bukit' }\end{array}$ \\
\hline
\end{tabular}

\subsection{Pemodelan Topik dengan LDA}

Tahap kelima pada penelitian ini adalah pemodelan topik menggunakan metode LDA. Masing-masing sentimen positif dan negatif akan diproses menggunakan metode LDA untuk mengetahui interpretasi topik utama yang sering dibahas oleh wisatawan pada kedua kelas sentimen tersebut. Prinsip dasar dari LDA adalah setiap dokumen direpresentasikan sebagai campuran topiktopik yang tersembunyi dan belum diketahui, dimana setiap topik terdiri dari distribusi banyak kata [8]. Blei merepresentasikan metode LDA sebagai sebuah probabilistic model seperti ditunjukkan pada Gambar 2 [17].

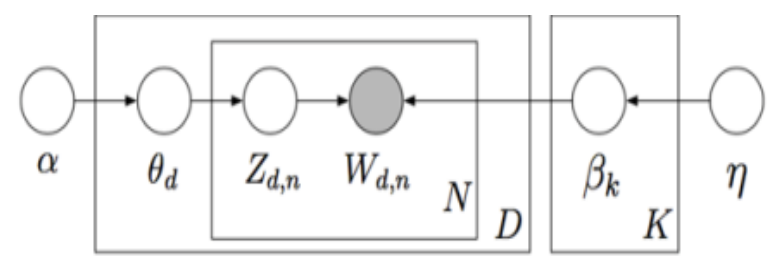

Gambar 2. Representasi Model LDA

Berdasarkan ilustrasi pada gambar 2 maka LDA dapat digambarkan secara khusus penggunaan notasi-notasi matematika dapat dilihat pada persamaan 2 [17].

$p\left(\beta_{1: k}, \theta_{1: D}, Z_{1: D}, W_{1: D}\right)=\prod_{i=1}^{k} p\left(\beta_{i}\right) \prod_{d=1}^{D} p\left(\theta_{d}\right)$
$\left(\prod_{n-1}^{N} p\left(Z_{d, n} \mid \theta_{d}\right) p\left(W_{d, n} \mid \beta_{1: k}, Z_{d, n}\right)\right)$ 
D adalah kumpulan dokumen, $\mathrm{K}$ adalah kumpulan topik, yaitu proses pembersihan data dari unsur hastag, url, $\mathrm{N}$ adalah jumlah kata dalam dokumen $\left(\mathrm{N}_{\mathrm{d}}\right), \mathrm{W}_{\mathrm{d}, \mathrm{n}}$ adalah tanda baca, kata yang berulang, mention, karakter dan kata ke-n pada dokumen $\mathrm{d}, \mathrm{Z}_{\mathrm{d}, \mathrm{n}}$ adalah topik ke-n pada kelebihan spasi, kemudian dilanjutkan dengan proses dokumen $\mathrm{d}, \theta_{\mathrm{d}}$ adalah jumlah topik per dokumen yang text transformation yang meliputi proses case folding terindentifikasi, $\beta_{\mathrm{k}}$ adalah distribusi topik pada tokenisasi, stopword removal, lematisasi, pembobotan vocabulary serta $\alpha, \eta$ adalah parameter dirichlet [17].

Secara umum cara kerja metode LDA pada penelitian ini adalah [18]:

dan ekstraksi fitur. Hasil preprocessing data menunjukkan bahwa tidak semua tweet dapat digunakan sebagai dataset, dimana jumlah data yang memenuhi kriteria sebanyak 9.496 data dengan pembagian 8.996

a. Membuat kamus dan korpus dari kumpulan sentimen positif dan negatif

sentimen positif dan 500 sentimen negatif. Jumlah data yang tidak sama (imbalance data) untuk setiap kelasnya

b. Melakukan inisialisasi parameter yaitu jumlah dokumen, jumlah topik, jumlah iterasi, random state, nilai alpha, nilai beta dan lain-lain.

c. Menentukan kata-kata untuk topik tertentu berdasarkan distribusi dirichlet.

d. Menampilkan probabilitas kata per topik

e. Mengulang alur b sampai d untuk semua kata dalam korpus

\subsection{Pengujian}

Tahap keenam dari penelitian ini adalah pengujian kinerja dari metode. Pengujian algoritma naive bayes dilakukan menggunakan metode confusion matrix berdasarkan pengukuran akurasi, precision, recall dan specificity seperti yang diperlihatkan persamaan 3, 4, 5 dan 6.

Akurasi $=\frac{T P+T N}{T P+F P+F N+T N}$

Precision $=\frac{T P}{T P+F P}$

Recall $=\frac{T P}{T P+F N}$

Specificity $=\frac{T N}{T N+F P}$

dengan TP adalah True Positive, TN adalah True Negative, FP adalah False Positive dan FN adalah False Negative [19].

Pengujian LDA dilakukan dengan melihat nilai koherence topik yaitu seberapa mudah topik tersebut diinterpretasikan menggunakan rumus pada persamaan 7.

$$
\text { Coherence }(V)=\sum_{\left(v_{i}, v_{j}\right) \in V} \operatorname{Score}\left(v_{i}, v_{j}, \in\right)
$$

dengan $\mathrm{V}$ adalah kumpulan kata untuk menjelaskan sebuah topik dan $\epsilon$ adalah faktor smoothing untuk mengembalikan nilai ke bilangan ril [20].

\section{Hasil dan Pembahasan}

\subsection{Dataset}

Data yang berhasil dikumpulkan sebanyak 12.971 tweet kemudian dilakukan pelabelan manual oleh 3 orang anotator untuk dikelompokan menjadi 2 kelas yaitu kelas positif dan kelas negatif. Proses pemilihan label tweet dilakukan dengan memilih label mayoritas yang diberikan oleh 3 orang anotator. Tahapan selanjutnya dimana jumlah data kelas positif lebih besar daripada kelas negatif. Imbalance data yang terjadi akan berpengaruh terhadap hasil prediksi dari model yang dibuat karena data training lebih dominan pada satu kelas saja. Untuk mengatasi permasalahan tersebut diterapkan teknik undersampling atau pengurangan jumlah data pada kelas mayoritas agar jumlah data menjadi sama dengan kelas minoritas. Pembagian dataset setelah diterapkan teknik undersampling adalah 500 tweet kelas positif dan 500 tweet kelas negatif.

Profile hasil klasifikasi untuk kelas positif dan negatif dapat dilihat pada visualisasi word cloud seperti yang ditunjukkan Gambar 3 dan 4. Pada kelas positif sering muncul kata Lombok, gili, pantai, hotel, sunrise, good, love, beautiful sedangkan pada kelas negatif kata yang sering muncul adalah sampah, gempa bumi, toilet, rinjani, gunung dan pantai. Dari kata-kata yang sering muncul pada word cloud positif dapat disimpulkan bahwa pantai dan gili trawangan menjadi tujuan wisata favorit wisatawan sedangkan untuk kelas negatif opini wisatawan lebih banyak mengarah ke masalah sampah.

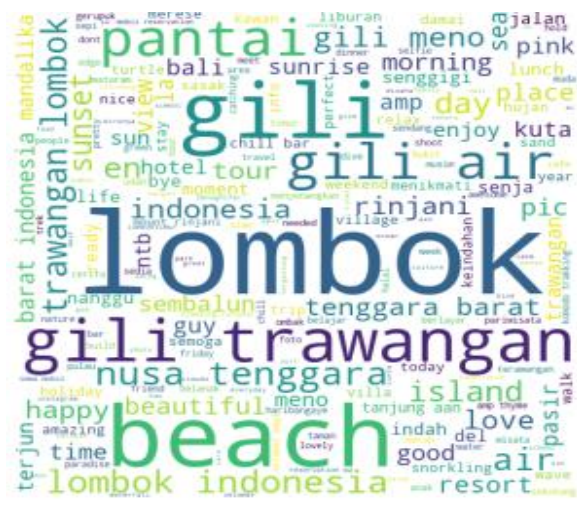

Gambar 3. Tampilan word cloud kelas positif

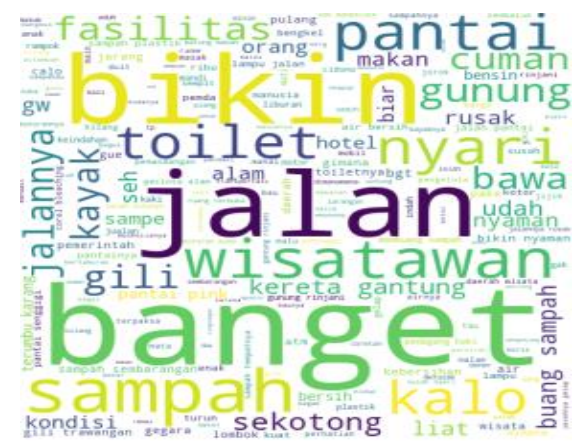

Gambar 4. Tampilan word cloud kelas negatif 


\subsection{Klasifikasi Naive Bayes}

Proses klasifikasi diawali dengan membagi dataset menjadi 2 bagian yaitu $80 \%$ data training dengan jumlah 800 tweet dan $20 \%$ data testing dengan jumlah 200 tweet. Data training digunakan untuk membangun model menggunakan algoritma multinomial naive bayes. Data testing digunakan untuk mengevaluasi perfoma model yang diperoleh melalui proses training. Proses training dimulai dengan menghitung nilai prior dari setiap kelas (positif dan negatif) setelah itu dilanjutkan dengan menghitung peluang term ke $\mathrm{n}$ pada sebuah dokumen. Kemudian dilanjutkan menghitung peluang sebuah dokumen masuk ke dalam suatu kelas dan tahapan terakhir adalah menentukan kelas dokumen dengan memilih nilai probabilitas tertinggi.

Pengujian model menggunakan metode confusion matrix, sebanyak 200 tweet akan diujicobakan untuk mengetahui perfoma model berdasarkan akurasi, presisi, recall dan spesifisitas. Metode confusion matrix dipilih karena mampu memberikan perbandingan hasil klasifikasi model dengan klasifikasi sebenarnya menggunakan 4 kombinasi nilai prediksi yaitu True Positive (TP) menunjukkan, False Positive (FP), False Negative (FN) dan True Negative (TN). Selain itu metode confusion matrix cocok untuk mengukur kinerja dari model klasifikasi yang menghasilkan dua output kelas seperti pada penelitian ini yaitu kelas positif dan negatif.

Berdasarkan hasil pengujian yang diperlihatkan pada tabel 4 menggunakan 200 tweet diperoleh 99 tweet masuk kelas positif dan 101 tweet masuk kelas negatif. Sedangkan hasil prediksi model menunjukkan bahwa prediksi untuk kelas positif dan benar adalah 83 tweet, prediksi untuk kelas negatif dan benar adalah 101 tweet, prediksi kelas positif dan salah adalah 0 serta prediksi kelas negatif dan salah adalah 16 tweet.

Tabel 4. Hasil matriks konfusi metode Naive Bayes

\begin{tabular}{lcc}
\hline \multicolumn{1}{c}{ Prediksi } & Aktual & \\
& Positif & Negatif \\
\hline Positif & 83 & 0 \\
Negatif & 16 & 101 \\
\hline
\end{tabular}

Hasil matrik konfusi diatas dijadikan acuan untuk perhitungan kinerja model dengan parameter akurasi, presisi, recall dan spesifisitas. Hasil perhitungan menunjukkan nilai akurasi model sebesar $92 \%$, presisi $100 \%$, recall 83,84\% dan Spesifisitas $100 \%$. Sehingga secara keseluruhan dapat disimpulkan bahwa metode naive bayes memiliki kinerja yang baik untuk mengklasifikasi sentimen dengan topik pariwisata Lombok.

\subsection{Pemodelan topik dengan LDA}

Data hasil sentimen akan dieksplorasi lebih lanjut menggunakan metode Laten Dirichlet Alocation (LDA). Pemodelan topik dilakukan untuk masing-masing kelas yaitu kelas positif dan kelas negatif. Tujuan pemodelan topik pada penelitian ini untuk menggali informasi dari kumpulan opini wisatawan yang pernah berkunjung ke Lombok. Informasi-informasi tersebut akan diinterpretasikan dalam bentuk kumpulan topik utama pada kelas positif dan negatif. Tahap awal dari pemodelan topik adalah membuat dictionary dan corpus untuk kelas positif serta negatif. Data yang digunakan merupakan dataset yang sama untuk klasifikasi naive bayes sebanyak 500 tweet kelas positif dan 500 tweet kelas negatif.

Tahapan penting pada proses pemodelan topik adalah pembentukan kamus dan korpus untuk data kelas positif dan kelas negatif. Selanjutnya dilakukan proses pembentukan model LDA menggunakan bantuan library gensim. Langkah awal adalah menetapkan nilai parameter yang akan digunakan seperti nomor topik, random state $=100$, update every $=1$, chunksize $=100$, passes $=10$, alpha $=$ auto. Penelitian ini akan mengambil rentang 1 sampai 20 topik untuk diuji guna mencari kelompok topik terbaik. Topik yang dihasilkan dari pemodelan topik belum tentu mudah untuk diinterpretasikan. Oleh karena itu dilakukan perhitungan koherensi topik untuk membedakan mana topik yang baik dan buruk. Indikator suatu topik dikatakan baik berdasarkan tingkat kemudahan kata-kata di dalam topik untuk ditafsirkan secara semantik, sedangkan suatu topik dikatakan buruk jika kata-kata di dalam topik sulit untuk dimaknai.

Hasil perhitungan nilai koherensi untuk topik pada kelas positif dan negatif ditunjukkan pada tabel 5 . Berdasarkan hasil perhitungan pada tabel 5, nilai koherensi terbaik untuk kelas positif diperoleh pada kelompok ke 8 dengan nilai 0,613 sedangkan untuk kelas negatif diperoleh pada kelompok ke 12 dengan nilai 0,528. Semakin tinggi nilai koherensi suatu topik maka semakin mudah topik tersebut diinterpretasikan maknanya berdasarkan kumpulan kata yang menyusunnya, dengan kata lain semakin sering kata-kata dalam topik tersebut muncul secara bersamaan maka nilai koherensi dari topik tersebut semakin tinggi. Kelompok kata-kata penyusun topik untuk kelas positif dan negatif dapat dilihat pada tabel 6 dan 7 .

Berdasarkan tabel 6 terdapat 8 topik yang dapat diinterpretasikan untuk kelas positif. Hasil interpretasi topik digunakan untuk melihat tren komentar wisatawan terhadap pariwisata Lombok baik itu dilihat dari sisi keindahan alamnya, kenyamanan, harapan wisatawan, makanan, dan lain-lain. Hasil interpretasi topik untuk kelas positif adalah Topik " 0 " mengandung informasi wisatawan banyak yang datang ke pantai pink pada saat weekend. Topik " 1 " mengandung informasi air terjun di Sembalun sangat indah. Topik " 2 " mengandung informasi selain Pulau Bali, Nusa Tenggara Barat mempunyai pantai yang indah. Topik " 3 " mengandung informasi keindahan sunset di gili meno, air dan trawangan. Topik "4" mengandung informasi keindahan 
pantai gili nanggu dapat dinikmati dari hotel sambil jalan. Topik "2" mengandung informasi banyak makan siang. Topik "5" mengandung informasi sunrise ditemukan sampah di gunung rinjani. Topik " 3 " di gili trawangan. Topik " 6 " mengandung informasi mengandung informasi fasilitas toilet umum masih pantai senggigi dan tanjung aan merupakan pantai terbatas. Topik "4" mengandung informasi menolak dengan pemandangan mengagumkan di NTB. Topik "7" pembangunan kereta gantung gunung rinjani. Topik "5" mengandung informasi jasa sewa mobil untuk tour mengandung informasi coral bleaching terumbu karang. wisata.
Tabel 5. Nilai koherensi topik

\begin{tabular}{ccc}
\hline \multirow{2}{*}{ Topik } & \multicolumn{2}{c}{ Koherensi } \\
& Positif & Negatif \\
\hline 1 & 0,582 & 0,409 \\
2 & 0,584 & 0,439 \\
3 & 0,596 & 0,459 \\
4 & 0,604 & 0,478 \\
5 & 0,606 & 0,527 \\
6 & 0,616 & 0,472 \\
7 & 0,612 & 0,510 \\
8 & 0,613 & 0,512 \\
9 & 0,581 & 0,489 \\
10 & 0,556 & 0,510 \\
11 & 0,552 & 0,521 \\
12 & 0,553 & 0,528 \\
13 & 0,500 & 0,469 \\
14 & 0,510 & 0,465 \\
15 & 0,486 & 0,457 \\
16 & 0,475 & 0,443 \\
17 & 0,462 & 0,421 \\
18 & 0,451 & 0,423 \\
19 & 0,444 & 0,430 \\
20 & 0,469 & 0,424 \\
\hline
\end{tabular}

Tabel 6. Kumpulan topik untuk kelas positif

\begin{tabular}{|c|c|c|c|}
\hline Topik 0 & Topik 1 & Topik 2 & Topik 3 \\
\hline beach & lombok & nusa & gili \\
\hline place & indonesia & tenggara & trawangan \\
\hline pink & air & barat & meno \\
\hline time & pic & morning & en \\
\hline selamat & island & indonesia & lombok \\
\hline nice & sembalun & pasir & air \\
\hline weekend & terjun & good & sea \\
\hline pagi & senja & pantai & beautiful \\
\hline moment & kuta & bali & sunset \\
\hline dive & mandalika & selfi & gilis \\
\hline Topik 4 & Topik 5 & Topik 6 & Topik 7 \\
\hline lombok & day & lombok & rinjani \\
\hline pantai & sunrise & beach & tour \\
\hline love & trawangan & happy & sewa \\
\hline view & beach & ntb & mobil \\
\hline hotel & enjoy & aan & kawan \\
\hline keindahan & happy & resort & info \\
\hline nanggu & semoga & senggigi & bar \\
\hline halal & semaian & indonesia & chill \\
\hline indah & minggu & amazing & wisata \\
\hline lunch & angkatan & village & life \\
\hline
\end{tabular}

Topik "6" mengandung informasi banyak kotoran kuda di jalan. Topik "7" mengandung informasi musholla kurang bersih. Topik " 8 " mengandung informasi trotoar untuk pejalan kaki masih jarang. Topik "9" mengandung informasi ditemukan banyak coretan pada batu di gunung rinjani dan air terjun benang kelambu. Topik "10" mengandung informasi penurunan jumlah wisatawan akibat gempa. Topik "11" mengandung informasi penutupan gunung rinjani akibat kebakaran hutan.

Tabel 7. Kumpulan topik untuk kelas negatif

\begin{tabular}{|c|c|c|c|}
\hline Topik 0 & Topik 1 & Topik 2 & Topik 3 \\
\hline pantai & lampu & bawa & fasilitas \\
\hline nyari & jalan & gunung & kotor \\
\hline sampah & gelap & turun & jumlah \\
\hline buang & pantai & puntung & bau \\
\hline botol & penerangan & rinjani & campur \\
\hline plastik & malam & sampah & cewek \\
\hline pecinta & pink & rokok & pantai \\
\hline sembarangan & pasang & pulang & toilet \\
\hline gili & buang & kotor & umum \\
\hline bikin & jarang & alam & sedikit \\
\hline Topik 4 & Topik 5 & Topik 6 & Topik 7 \\
\hline kereta & karang & jalan & air \\
\hline gantung & terumbu & bikin & mati \\
\hline rinjani & coral & liat & sulit \\
\hline lombok & bleaching & wisata & musholla \\
\hline tolak & mata & kuda & pantai \\
\hline manusia & memandang & kotoran & cidomo \\
\hline sampai & mengalami & daerah & salah \\
\hline wisata & perairan & kondisi & uang \\
\hline gunung & sebelah & lombok & bersih \\
\hline indah & diambil & cidomo & kurang \\
\hline Topik 8 & Topik 9 & Topik 10 & Topik 11 \\
\hline trotoar & coretan & gempa & tutup \\
\hline jalan & sembarangan & bumi & rinjani \\
\hline kaki & rinjani & lombok & bakar \\
\hline jarang & batu & turun & pendaki \\
\hline lengkap & rembige & sepi & orang \\
\hline sarana & cidomo & tumpukan & gunung \\
\hline buat & kelambu & pembenahan & wisata \\
\hline belum & lingkungan & jalan & arah \\
\hline ATM & sadar & lokal & cuman \\
\hline hotel & banget & wisatawan & main \\
\hline
\end{tabular}

Visualisasi pemodelan topik pada penelitian ini dibuat dalam bentuk pyLDAvis ditunjukkan oleh Gambar 5 dan Berdasarkan tabel 7 terdapat 12 topik yang dapat 6. Pada Gambar 5 menunjukkan visualisasi untuk kelas diinterpretasikan untuk kelas negatif yaitu topik "0" positif dan Gambar 6 menunjukkan visualisasi untuk mengandung informasi banyaknya sampah plastik dan kelas negatif. Berdasarkan visualisasi sebaran topik yang botol di pantai. Topik "1" mengandung informasi diperlihatkan pada kelas positif dan negatif terdapat disepanjang jalan pantai pink jarang terpasang lampu beberapa topik saling beririsan yang menandakan topik- 
topik tersebut mempunyai beberapa kata penyusun yang khususnya gili trawangan dan pantai senggigi. sama. Topik-topik yang saling beririsan pada kelas Sedangkan untuk kelas negatif topik yang banyak positif yaitu topik 7 dengan topik 8, topik 5 dengan topik dibicarakan adalah mengenai sampah.

8 , topik 8 dengan topik 6 dan topik 3 dengan topik 4 sedangkan topik-topik yang saling beririsan pada kelas negatif yaitu topik 2 dengan 5 dan topik 5 dengan 4 , serta topik 7 dengan topik 12 , topik 9 , topik 6 , topik 10 , topik 11.

Saran untuk pengembangan penelitian ini kedepannya adalah menambah jumlah dataset yang digunakan serta melakukan identifikasi terhadap kata-kata yang mempunyai makna ambigu sehingga mampu meningkatkan nilai akurasi pada model klasifikasi sentimen dan pemodelan topik. Selain itu perlu dilakukan penambahan metode selain koherensi untuk pengujian validasi topik yang dihasilkan pada LDA seperti uji kesesuaian distribusi topik.

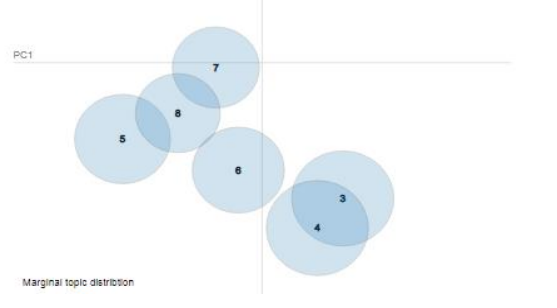

Gambar 5. Visualisasi topik kelas positif
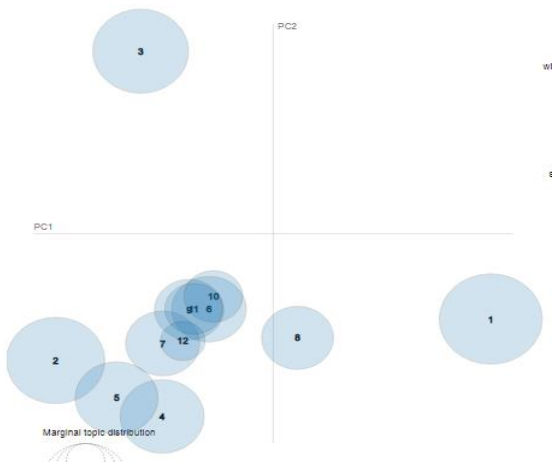

Gambar 6. Visualisasi topik kelas negatif

\section{Kesimpulan}

Penelitian ini berhasil melakukan analisis sentimen menggunkan metode Naive Bayes serta pemodelan topik dengan metode Latent Dirichlet Allocation (LDA) untuk topik pariwisata Lombok. Berdasarkan hasil analisis sentimen diperoleh 9.496 tweet dengan pembagian 8.996 tweet sentimen positif dan 500 tweet sentimen negatif, sehingga dapat disimpulkan bahwa lebih banyak wisatawan memberikan respon positif daripada negatif terhadap pariwisata Lombok. Hasil pengujian menunjukkan bahwa algoritma Naive Bayes mampu mengklasifikasi sentimen wisatawan dengan baik yang ditunjukkan dengan pengukuran hasil kinerja algoritma melalui 4 parameter yaitu nilai akurasi sebesar $92 \%$, presisi $100 \%$, recall $83,84 \%$ dan Spesifisitas $100 \%$. Sedangkan pemodelan topik menggunakan algoritma LDA menghasilkan topik terbaik untuk kelas positif pada 8 topik dengan nilai koherensi 0,613 kemudian untuk kelas negatif topik terbaik pada 12 topik dengan nilai koherensi 0,528 . Hasil interpretasi topik-topik yang sering diperbincangkan oleh masyarakat pada kelas positif yaitu tentang keindahan pantai di Pulau Lombok

\section{Ucapan Terimakasih}

Peneliti memberikan apresiasi yang sebesar-besarnya serta mengucapkan terima kasih kepada Kementerian Riset dan Teknologi/Badan Riset dan Inovasi Nasional sebagai pemberi dukungan dana melalui hibah kompetitif nasional skim dosen pemula tahun pelaksanaan 2020 .

\section{Daftar Rujukan}

[1] N. Islamy, "Analisis Sektor Potensial, Dapatkah Pariwisata Menjadi Lokomotif Baru Ekonomi Nusa Tenggara Barat?," J. Indones. Tour. Hosp. Recreat., vol. 2, no. 1, pp. 1-10, 2019.

[2] K. a n o m K a n o m, "Strategi Pengembangan Kuta Lombok Sebagai Destinasi Pariwisata Berkelanjutan," J. Master Pariwisata, vol. 1, pp. 25-42, 2015.

[3] H. S. Utama, D. Rosiyadi, B. S. Prakoso, and D. Ariadarma, "Analisis Sentimen Sistem Ganjil Genap di Tol Bekasi Menggunakan Algoritma Support Vector Machine," J. RESTI (Rekayasa Sist. dan Teknol. Informasi), vol. 3, no. 2, pp. 243$250,2019$.

[4] S. N. J. Fitriyyah, N. Safriadi, and E. E. Pratama, "Analisis Sentimen Calon Presiden Indonesia 2019 dari Media Sosial Twitter Menggunakan Metode Naive Bayes," J. Edukasi dan Penelit. Inform., vol. 5, no. 3, pp. 279-285, 2019.

[5] R. Ferdiana, F. Jatmiko, D. D. Purwanti, A. S. T. Ayu, and W. F. Dicka, "Dataset Indonesia untuk Analisis Sentimen," J. Nas. Tek. Elektro dan Teknol. Inf., vol. 8, no. 4, pp. 334-339, 2019.

6] A. Alamsyah, W. Rizkika, D. D. A. Nugroho, F. Renaldi, and S. Saadah, "Dynamic large scale data on Twitter using sentiment analysis and topic modeling case study: Uber," in 2018 6th International Conference on Information and Communication Technology, ICoICT 2018, 2018, vol. 0, no. c, pp. 254-258.

[7] R. Ardianto, T. Rivanie, Y. Alkhalifi, F. S. Nugraha, and W. Gata, "Sentiment Analysis on E-Sports For Education Curriculum Using Naive Bayes and Support Vector Machine," J. Comput. Sci. Inf., vol. 13, no. 2, pp. 109-122, 2020.

[8] M. Cendana and S. D. H. Permana, "Pra-Pemrosesan Teks Pada Grup Whatsapp Untuk Pemodelan Topik," Junal Mantik Penusa, vol. 3, no. 3, pp. 107-116, 2019.

[9] O. Somantri and D. Dairoh, "Analisis Sentimen Penilaian Tempat Tujuan Wisata Kota Tegal Berbasis Text Mining," $J$. Edukasi dan Penelit. Inform., vol. 5, no. 2, pp. 191-196, 2019.

10] S. Fanissa, M. A. Fauzi, and S. Adinugroho, "Analisis Sentimen Pariwisata di Kota Malang Menggunakan Metode Naive Bayes dan Seleksi Fitur Query Expansion Ranking," J. Pengemb. Teknol. Inf. dan Ilmu Komput., vol. 2, no. 8, pp. 2766-2770, 2018.

11] Murnawan and A. Sinaga, "Pemanfaatan Analisis Sentimen untuk Pemeringkatan Popularitas Tujuan Wisata," J. Penelit. Pos dan Inform., vol. 7, no. 2, pp. 109-120, 2017.

[12] M. A. Ulfa, B. Irmawati, and A. Y. Husodo, “Twitter Sentiment Analysis using Naive Bayes Classifier with Mutual Information 
Feature Selection,” J. Comput. Sci. Informatics Eng., vol. 2, no. 2, pp. 106-111, 2018.

[13] G. R. Gustisa Wisnu, Ahmadi, A. R. Muttaqi, A. B. Santoso, P. K. Putra, and I. Budi, "Sentiment analysis and topic modelling of 2018 central java gubernatorial election using twitter data," 2020 Int. Work. Big Data Inf. Secur. IWBIS 2020, pp. 35-40, 2020.

[14] P. M. R. C. Dinatha and N. A. Rakhmawati, "Komparasi Term Weighting dan Word Embedding pada Klasifikasi Tweet Pemerintah Daerah," J. Nas. Tek. Elektro dan Teknol. Inf., vol. 9, no. 2, pp. 155-161, 2020.

[15] P. M. Prihatini, "Implementasi Ekstraksi Fitur Pada Pengolahan Dokumen Berbahasa Indonesia," J. Matrix, vol. 6, no. 3, pp. 174-178, 2016.

[16] V. Balakrishnan and W. Kaur, "String Based Multinomial Naive
Bayes for Emotion Detection among Facebook Diabetes Community," Procedia Comput. Sci., vol. 159, pp. 30-37, 2019.

17] D. Blei, L. Carin, and D. Dunson, "Probabilistic topic models," IEEE Signal Process. Mag., vol. 27, no. 6, pp. 55-65, 2010.

[18] D. M. Blei, A. Y. Ng, and M. I. Jordan, "Latent Dirichlet Allocation," J. Mach. Learn. Res., vol. 3, pp. 993-1022, 2003.

[19] W. Chen, Z. Xu, X. Zheng, Q. Yu, and Y. Luo, "Research on sentiment classification of online travel review text," Appl. Sci., vol. 10 , no. $15,2020$.

[20] K. Stevens, P. Kegelmeyer, D. Andrzejewski, and D. Buttler, "Exploring topic coherence over many models and many topics," in EMNLP-CoNLL 2012 - 2012 Joint Conference on Empirical Methods in Natural Language Processing and Computational Natural Language Learning, Proceedings of the Conference, 2012, no. July, pp. 952-961. 